\title{
Utilization of Biogas Liquid Waste For Starter In The Fermentation of Rice Husk As A Potential Feedstuff
}

\author{
Osfar Sjofjan*, Danung Nur Adli, Irfan Hadji Djunaidi and Ariwandika Sapto Kuncoro \\ Faculty of Animal Science, University of Brawijaya, Malang, Indonesia \\ *Corresponding author e-mail: osofjan@yahoo.com
}

\begin{abstract}
The research was aimed to evaluate the effect of biogas liquid waste as a fermentation starter of rice husk on the nutrient content, gross energy and bulk density. A laboratory experiment was conducted in a Completely Randomized Design (CRD) with a factorial pattern $(6 \times 5)$ using different levels of biogas waste liquid, namely $\mathrm{P} 0$-treatment ( $0 \%$ negative control), $\mathrm{P} 0+$ (Cellulomonas sp as positive control), P1 (5\%), P2 (10\%), P3 (15\%), P4 (20\%) ml/g. The experiment also included various incubation time, i.e. T0 (0 day as control group), T1 (7 days), T2 (14 days), T3 (21 days) and T4 (28 days). The variables measured was the content of ash, crude protein, crude fiber, crude fat, gross energy and bulk density. Data were subject to analysis of variance (Anova) and CRD Factorial pattern, as well as Duncan's Multiple Range Test for any significant difference. The results revealed that the level of biogas liquid waste and the incubation time significantly affected the nutrient content, gross energy and bulk density of rice husk. The interaction between the level of liquid waste biogas and incubation time was highly significant on the nutrient content, gross energy and bulk density. It can be concluded that the liquid waste of biogas as a starter in the fermentation of rice husk could increase the content of inorganic material, crude protein, crude fat, and gross energy, and lower content of crude fiber and total density of rice husk.
\end{abstract}

Keywords: rice husk, biogas liquid waste, fermentation, alternative feed

\begin{abstract}
Abstrak. Tujuan dari penelitian ini adalah untuk mengetahui jumlah penggunaan limbah cair biogas dan lama inkubasi yang digunakan agar menghasilkan komposisi sekam padi yang paling baik sebagai bahan pakan alternatif. Materi yang digunakan adalah limbah cair biogas dan sekam padi. Metode yang digunakan adalah metode percobaan Laboratorium dengan menggunakan Rancangan Acak Lengkap (RAL) pola Faktorial (6x5) dengan 4 ulangan. Faktor pertama adalah level pemberian limbah cair biogas $(P)$ yang terdiri dari perlakuan P0- (0\% kontrol negatif), P0+ (Cellulomonas sp kontrol positif), P1 (5\%), P2 (10\%), P3 (15\%), dan P4 (20\%) ml/g, serta faktor kedua adalah waktu inkubasi yang terdiri dari T0 (0 hari kontrol), T1 (7 hari), T2 (14 hari), T3 (21 hari), dan T4 (28 hari). Variabel yang diamati adalah kandungan nutrisi yang meliputi bahan anorganik, protein kasar, serat kasar, lemak kasar, gross energy, dan kerapatan jenis. Hasil dari penelitian ini menunjukkan bahwa pemberian limbah cair biogas dan waktu inkubasi memberikan pengaruh yang sangat nyata terhadap kandungan nutrisi, gross energy dan kerapatan jenis sekam padi. Hasil interaksi penggunaan level pemberian dan waktu inkubasi limbah cair biogas sebagai starter dalam proses fermentasi sekam padi memberikan pengaruh yang sangat nyata terhadap kandungan nutrisi, gross energy dan kerapatan jenis sekam padi. Peningkatan kualitas sekam padi yang meliputi peningkatan kandungan protein kasar, gross energy, lemak kasar, dan penurunan serat kasar, perlakuan terbaik terdapat pada pemberian limbah cair biogas sebanyak $15 \%(\mathrm{ml} / \mathrm{g})$ dengan waktu inkubasi selama 21 hari.
\end{abstract}

Kata kunci: sekam padi, limbah cair biogas, fermentasi, pakan alternative

\section{Introduction}

Rice bran has been widely used as a livestock feed but it is susceptible to be mixed with other materials to make refined rice bran and milled husk rice milled (Sjofjan et al., 2019) to produce low quality feed that may reduce the performance of livestock.

According to the Badan Pusat Statistik (2014), rice production in 2013 reached 71.28 million tons of dry milled grain. Meanwhile, $22 \%$ of the weight of paddy is husk (Nasution, 2006). However, rice husk exhibits nutrient digestibility and it contains ash/silica which is a potentially limiting factor in the use of chaff (Aderolu et al., 2007).

Fermentation is a method of processing feed material that aims to improve the quality of the feed material using microbes (Yunilas, 2009). 
Liquid waste biogas derived from an expenditure of biogas is rich in microorganisms; the microorganism that help to increase fermentation were cellulomonas sp (Gamayanti et al., 2012). Types of bacteria found in the biogas are genus Clostridium which is a fermentative bacteria that produce hydrogen (Fang et al., 2006). Based on the study above, the research was conducted to investigate the influence of liquid waste of biogas as a starter in the fermentation process of rice husk terms on the nutrient content and density of livestock feed ingredients.

\section{Materials and Methods}

The materials for this research were liquid waste of biogas and rice husk. The liquid waste biogas was derived from the waste of the biogas unit which was filtered and added micronutrients for the fermentation. Rice husk was milled to obtain the size of $\pm 1 \mathrm{~mm}$, then sterilized and added with liquid waste biogas. The rice husk was fermented and heated up to $60^{\circ} \mathrm{C}$ for 24 hours.

The tools to withdraw liquid waste biogas included glass beaker, filter cloth, and measuring cup. The fermentation was conducted using an analytical balance, autoclave, tray, sheet fabric, grinder and oven. For observation, a set of analysis tools proximate and gross energy were utilized. The bulk density was measured using analytical scales and measuring cups.

The experimental method was a laboratory experiment in a Completely Randomized Design (CRD) with a factorial pattern $(6 \times 5)$ with the treatment the level of provision of liquid waste biogas $(\mathrm{P})$ consisting of $\mathrm{PO}-(0 \%$ negative control), $\mathrm{PO}+$ (Cellulomonas $\mathrm{sp}$ as positive control), P1 (5\%), P2 (10\%), P3 (15\%), and P4 $(20 \%) \mathrm{ml} / \mathrm{g}$, and incubation time consisting of TO (0 day control), T1 (7 days), T2 (14 days), T3 (21 days), and T4 (28 days). The observed variables were the nutrients contents, i.e. inorganic materials, crude protein, crude fiber, crude fat, gross energy, and the density of the type. Data were analyzed by analyze of variance (anova) Factorial and any difference would be subjected to the Duncan's Multiple Range Test (Adli et al., 2018)

\section{Results and Discussion}

The effect of The Treatment level of Liquid Waste of Biogas and Incubation Time on The Proximate Composition of Rice Husk.

Table 1 demonstrated that the effect biogas liquid waste as a starter is significantly different $(P<0.01)$ across treatment to increase the ash, $\mathrm{CP}$, fat, and gross energy, as well as to reduce the content of $\mathrm{CF}$ and number density of rice husk. The observation on different incubation time of rice husk fermented with liquid waste of biogas showed a significant difference result $(P<0.01)$, where the longer the incubation time, the higher the content of ash, $\mathrm{CP}$, fat, and gross energy, but the lower the CF and total density.

\section{Inorganic Materials}

Table 1 shows that the level of liquid waste of biogas as a starter showed a significantly different result $(P<0.01)$ on the ash content of rice husk. Adli et al. (2017) explained that the higher the population of microbes, the more organic materials contained in the main ingredient that were utilized for the growth and development of microbes; as a result, the inorganic material in the fermentation was increased. It shows that the higher amount of liquid waste biogas as a starter would result in a bigger population of microbes.

Based on Table 1, the incubation time during the fermentation using liquid waste of biogas as a starter showed a significantly different result $(P<0.01)$ to increase the content of rice husk ash. The longer the time spent for the fermentation process, the higher the ash content. Adli et al. (2018) stated fermentation on organic materials used carbohydrates as the energy source for the growth and activity of 
microbes and mold; therefore, so the ash content in rice husk increased.

\section{Crude Protein}

Table 1 demonstrated that the level liquid waste of biogas as a starter was significantly different $(P<0.01)$ on the $C P$ of the rice husk. The CP of the control reached $6.60 \%$ where the rice husk was suspected to have been mixed with bran which contains a CP raised $6.88 \%$ (Adli et al., 2019). The increase in CP was linear to that of the starter. Mangunwidjaja et al. (2015) mentioned that one way to increase the protein content material was by cultivating microbial cells as a source of protein or sosingle cell protein (SCP).

The protein content of fermented rough rice husk increased very significantly $(P<0.01)$ than TO (without incubation) up to the time of incubation in T3 (21 days). The increase in the protein content of rough rice husk fermented with liquid waste biogas could be derived from microbes and mold that were growing within the incubation period. Suparjo and Nelson (2011) reported that the increase in protein content occurs because of the bioconversion of sugar to protein of the mycelium or single cell protein.

\section{Crude Fiber}

Based on Table 1, the level of liquid waste biogas provides a significant influence $(P<0.01)$ to the content of the crude fiber of the rice husk. Using liquid waste biogas by $20 \%$ (ml/g) produced the lowest percentage of crude fiber (CF) in the fermentation result. This result showed that the bigger the microbial population, the higher the crude fiber digestibility. Dosage was related to the magnitude of the microbial populations that determined whether or not the development of microbes to produce enzymes to remodel the substrate into simpler components (Lunar et al., 2012).

The incubation time significantly affected $(P<0.01)$ the crude fiber content in the rice husk. The longer incubation time as in T3 (21 days) would decrease the crude fiber. Adli et al. (2019) stated that the crude fiber decreased because of the formation of xylanase enzyme by microorganisms which increased up to day28 (Adli et al., 2019). Xylanase is an enzyme that could hydrolyze xylene or polymer contained in the hemicellulose (Ligyarohman et al., 2014).

Table 1. The effect of the level of provision and time of incubation on the nutrient content of rice husk

\begin{tabular}{|c|c|c|c|c|c|c|}
\hline \multirow{2}{*}{ Treatment } & \multicolumn{6}{|c|}{ The treatment level } \\
\hline & ash (\%) & $\mathrm{CP}(\%)$ & CF (\%) & Fat (\%) & GE (Kcal/kg) & Density (g/L) \\
\hline P0-(negative ) & $18,58 \pm 0,34^{a}$ & $6,60 \pm 0,69^{a}$ & $34,95 \pm 0,9^{c}$ & $6,34 \pm 0,34^{a}$ & $1939,12 \pm 100,45^{a}$ & $296,83 \pm 16,18^{d}$ \\
\hline P0+ (positive) & $18,57 \pm 0,48^{a}$ & $6,88 \pm 0,4^{b}$ & $35,89 \pm 0,85^{e}$ & $6,76 \pm 0,3^{b}$ & $1953,72 \pm 114,02^{b}$ & $292,85 \pm 15,33^{c}$ \\
\hline P1 (5\%) & $19,07 \pm 0,61^{b}$ & $7,34 \pm 0,33^{c}$ & $34,11 \pm 0,71^{b}$ & $7,05 \pm 0,32^{f}$ & $1975,85 \pm 53,51^{c}$ & $291,19 \pm 21,91^{b}$ \\
\hline P2 (10\%) & $20,21 \pm 0,79^{d}$ & $7,32 \pm 1,01^{c}$ & $35,35 \pm 1,44^{d}$ & $6,94 \pm 0,41^{e}$ & $2007,88 \pm 60,52^{d}$ & $290,55 \pm 25,61^{b}$ \\
\hline P3 (15\%) & $20,94 \pm 0,86 \mathrm{e}$ & $7,66 \pm 1,04^{d}$ & $35,5 \pm 3,09 d$ & $6,87 \pm 0,45^{d}$ & $2016,24 \pm 130,53^{d}$ & $283,66 \pm 23,78^{a}$ \\
\hline \multirow[t]{2}{*}{ P4 (20\%) } & $19,99 \pm 0,86^{c}$ & $7,95 \pm 0,66 \mathrm{e}$ & $33,7 \pm 1,63^{a}$ & $6,81 \pm 0,55^{c}$ & $2034,45 \pm 99,2^{e}$ & $283,61 \pm 27,76^{a}$ \\
\hline & \multicolumn{6}{|c|}{ The effect of incubation time } \\
\hline T0 (Odays) & $18,72 \pm 0,49^{a}$ & $6,91 \pm 0,9^{a}$ & $36,63 \pm 2,13^{e}$ & $7,05 \pm 0,64^{d}$ & $1916,60 \pm 52,53^{a}$ & $314,48 \pm 3,31^{e}$ \\
\hline T1 (7 days) & $19,44 \pm 1,28^{b}$ & $7,35 \pm 0,4^{d}$ & $36,04 \pm 1,16^{d}$ & $6,63 \pm 0,39^{a}$ & $1930,54 \pm 46,15^{b}$ & $303,59 \pm 6,58^{d}$ \\
\hline T2 (14 days) & $19,55 \pm 1,01^{b}$ & $7,02 \pm 0,82^{b}$ & $34,43 \pm 0,75^{c}$ & $6,89 \pm 0,39 c$ & $1927,69 \pm 17,51^{b}$ & $292,35 \pm 6,78^{c}$ \\
\hline T3 (21 days) & $19,94 \pm 1,22^{c}$ & $8,01 \pm 1,03^{e}$ & $33,55 \pm 1,07^{a}$ & $6,78 \pm 0,41^{b}$ & $2034,84 \pm 91,24^{c}$ & $285,56 \pm 8,6^{b}$ \\
\hline T4 (28 days) & $20,16 \pm 0,85^{d}$ & $7,17 \pm 0,51^{c}$ & $33,94 \pm 1,19^{b}$ & $6,62 \pm 0,24^{a}$ & $2129,69 \pm 59,08^{d}$ & $252,93 \pm 10,9^{a}$ \\
\hline
\end{tabular}

\footnotetext{
*Superscript different on the same column indicate differences that were significant different $(\mathrm{P}<0,01)$
} 


\section{Fat}

Table 1 demonstrated that the level of liquid waste biogas significantly affects $(P<0.01)$ the fat content of the rough rice husks. The highest fat content was observed in the use of $5 \% \mathrm{ml} / \mathrm{g}$ liquid waste biogas rather than control group or the higher level. Safitri (2014) reported that using a wide variety of bacteria and levels of provision would decrease the fat content of substrate. The increase of crude fat was linear to that of cell mass of fungi and yeast. Yeast cell has a high potential to increase the fat content of the rough substrate because yeast cell contains $4.9 \%$ crude fat (Safitri and Wahyudi, 2011).

The fat content of rough rice husk fermented with different incubation time showed a significantly different decrease $(P<0.01)$. The highest crude fat was observed in TO (without incubation) and the lowest was in treatment T4 (28 days). According to Mirwandhono et al. (2006), fermentation time could increase the levels of fat in the fermentation of 6 days. The increased fat content during the fermentation process was due to the mass of microbial cells that grew and multiplied on the media. The content of crude fat increased in the early phase (day 7) and decreased until day-28. A study by Joseph et al. (2008) reported that after 96 hours the fat content in the substrate decreased because it could have been used to form the enzyme lipolytic extracellular by fungi in the lipid and fatty acid of the substrate (Sjofjan et al., 2020)

\section{Gross Energy}

Table 1 indicates that the level of liquid waste biogas significantly affects $(P<0.01)$ the gross energy content of the rice husk. The higher level of liquid waste biogas could increase the gross energy of rice husk due to microbial decomposition of components of the complex cellulose into glucose more (Telew et al., 2013). The gross energy of rice husk increased because of the formation of the xylanase enzyme during the fermentation which degraded xylene to simple sugars (Suryanata et al., 2013).

Based on Table 1, incubation time significantly affects $(P<0.01)$ the gross energy content of rice husk. The increased levels of energy gross could be due to the reorganization of carbohydrates easy to digest (NFE) and the compound of $\mathrm{N}$ by decomposing microorganisms. Aderolu et al. (2007) reported an increase in the content of gross energy of rice husk fermented with Trichoderma viride on the incubation period in days to 30 .

\section{Bulk Density}

The liquid waste biogas significantly affected $(P<0.01)$ the decrease of rice husk density. The decrease was suspected to have derived from a large number of microbes that changed the conditions of the substrate (more acidic) so the bonding fibers in the rice husk is became increasingly tenuous, hence, lowering the total density of the type and improving the bulky properties. Daniel et al. (2014) explained that the nature of bulky is the level of feed material due to the density of the feed material.

Table 1 demonstrates that the time of incubation was significantly different $(P<0.01)$ in decreasing the numbers of density type. Prabhu et al. (2014) stated that the fermentation of rice bran using yeast has reduced the bulk density up to $37.5 \%$ when incubated for 24 and 48 hours. Rice bran and rice husk share almost similar characteristics, and both are derived from the waste of rice milling. The increase in the pores of the rice husk due to the atmosphere of acid during the fermentation process can loosen the bonds of fiber (Bata, 2008). 
Table 2. The interaction between the treatment Levels and the incubation time on the content proximate the Rice Husk

\begin{tabular}{|c|c|c|c|c|c|c|c|}
\hline & PO- & $\mathrm{PO}+$ & P1 & $\mathrm{P} 2$ & P3 & P4 & Total \\
\hline & \multicolumn{7}{|c|}{ Inorganic material (\%) } \\
\hline TO & $18,23 \pm 0,06$ & $18,31 \pm 0,1$ & $18,32 \pm 0,04$ & $19,13 \pm 0,05$ & $19,51 \pm 0,05$ & $18,79 \pm 0,14$ & 112,29 \\
\hline T1 & $18,48 \pm 0,06$ & $18,09 \pm 0,07$ & $18,66 \pm 0,04$ & $21,48 \pm 0,01$ & $20,79 \pm 0,02$ & $19,16 \pm 0,07$ & 116,67 \\
\hline $\mathrm{T} 2$ & $18,35 \pm 0,04$ & $18,52 \pm 0,04$ & $18,96 \pm 0,09$ & $19,99 \pm 0,07$ & $20,87 \pm 0,09$ & $20,59 \pm 0,06$ & 117,29 \\
\hline T3 & $18,69 \pm 0,01$ & $18,46 \pm 0,01$ & $19,48 \pm 0,14$ & $20,47 \pm 0,05$ & $21,89 \pm 0,08$ & $20,64 \pm 0,1$ & 119,62 \\
\hline \multirow[t]{2}{*}{$\mathrm{T} 4$} & $19,16 \pm 0,01$ & $19,45 \pm 0,05$ & $19,95 \pm 0,23$ & $19,99 \pm 0,08$ & $21,64 \pm 0,1$ & $20,76 \pm 0,07$ & 120,95 \\
\hline & \multicolumn{7}{|c|}{ Crude Protein (\%) } \\
\hline TO & $6,46 \pm 0,02$ & $6,39 \pm 0,04$ & $7,14 \pm 0,02$ & $6,48 \pm 0,02$ & $6,21 \pm 0,02$ & $8,77 \pm 0,07$ & 41,45 \\
\hline $\mathrm{T} 1$ & $6,70 \pm 0,02$ & $6,92 \pm 0,03$ & $7,63 \pm 0,02$ & $7,76 \pm 0,001$ & $7,52 \pm 0,01$ & $7,55 \pm 0,03$ & 44,09 \\
\hline $\mathrm{T} 2$ & $5,73 \pm 0,01$ & $6,49 \pm 0,01$ & $6,91 \pm 0,03$ & $7,28 \pm 0,03$ & $8,34 \pm 0,03$ & $7,38 \pm 0,02$ & 42,13 \\
\hline T3 & $6,34 \pm 0,002$ & $7,19 \pm 0,004$ & $7,79 \pm 0,05$ & $8,94 \pm 0,02$ & $9,15 \pm 0,03$ & $8,67 \pm 0,04$ & 48,06 \\
\hline \multirow[t]{2}{*}{ T4 } & $\underline{7,79 \pm 0,003}$ & $7,41 \pm 0,02$ & $7,22 \pm 0,09$ & $6,16 \pm 0,02$ & $7,07 \pm 0,03$ & $7,36 \pm 0,02$ & 43,01 \\
\hline & \multicolumn{7}{|c|}{ Crude Fibre (\%) } \\
\hline TO & $36,59 \pm 0,12$ & $37,14 \pm 0,21$ & $33,02 \pm 0,07$ & $36,77 \pm 0,09$ & $40,16 \pm 0,1$ & $36,07 \pm 0,28$ & 219,76 \\
\hline $\mathrm{T} 1$ & $35,03 \pm 0,12$ & $36,19 \pm 0,13$ & $35,08 \pm 0,08$ & $37,30 \pm 0,01$ & $37,73 \pm 0,03$ & $34,93 \pm 0,13$ & 216,26 \\
\hline $\mathrm{T} 2$ & $34,55 \pm 0,07$ & $35,73 \pm 0,07$ & $34,02 \pm 0,16$ & $34,48 \pm 0,13$ & $34,49 \pm 0,14$ & $33,29 \pm 0,1$ & 206,56 \\
\hline T3 & $34,09 \pm 0,01$ & $34,59 \pm 0,02$ & $34,01 \pm 0,24$ & $34,38 \pm 0,08$ & $32,32 \pm 0,12$ & $31,90 \pm 0,15$ & 201,28 \\
\hline \multirow[t]{2}{*}{$\mathrm{T} 4$} & $34,48 \pm 0,02$ & $35,80 \pm 0,1$ & $34,41 \pm 0,4$ & $33,82 \pm 0,13$ & $32,79 \pm 0,14$ & $32,31 \pm 0,1$ & 203,61 \\
\hline & \multicolumn{7}{|c|}{ Fat (\%) } \\
\hline TO & $6,36 \pm 0,02$ & $6,24 \pm 0,04$ & $6,74 \pm 0,01$ & $7,56 \pm 0,02$ & $7,57 \pm 0,02$ & $7,82 \pm 0,06$ & 42,29 \\
\hline T1 & $6,17 \pm 0,02$ & $6,68 \pm 0,02$ & $7,35 \pm 0,02$ & $6,77 \pm 0,001$ & $6,45 \pm 0,01$ & $6,35 \pm 0,02$ & 39,77 \\
\hline $\mathrm{T} 2$ & $6,18 \pm 0,01$ & $6,89 \pm 0,01$ & $7,34 \pm 0,04$ & $7,05 \pm 0,03$ & $7,20 \pm 0,03$ & $6,73 \pm 0,02$ & 41,38 \\
\hline T3 & $6,01 \pm 0,002$ & $7,10 \pm 0,004$ & $7,22 \pm 0,05$ & $6,99 \pm 0,02$ & $6,60 \pm 0,03$ & $6,77 \pm 0,03$ & 40,69 \\
\hline \multirow[t]{2}{*}{ T4 } & $6,97 \pm 0,003$ & $6,87 \pm 0,02$ & $6,63 \pm 0,08$ & $6,33 \pm 0,03$ & $6,52 \pm 0,03$ & $6,38 \pm 0,02$ & 39,69 \\
\hline & \multicolumn{7}{|c|}{ Gross energy (Kkal/kg) } \\
\hline TO & $1849,19 \pm 6,25$ & $1847,83 \pm 10,53$ & $1925,77 \pm 4,01$ & $1942,97 \pm 4,76$ & $1952,49 \pm 4,87$ & $1981,36 \pm 15,14$ & 11499,61 \\
\hline $\mathrm{T} 1$ & $1897,91 \pm 6,42$ & $1899,57 \pm 6,92$ & $1972,29 \pm 4,56$ & $1995,35 \pm 0,36$ & $1868,83 \pm 1,68$ & $1949,25 \pm 7,13$ & 11583,21 \\
\hline $\mathrm{T} 2$ & $1903,46 \pm 3,99$ & $1923,70 \pm 3,61$ & $1917,53 \pm 9,06$ & $1951,10 \pm 7,18$ & $1925,10 \pm 7,92$ & $1945,30 \pm 5,6$ & 11566,18 \\
\hline T3 & $1915,55 \pm 0,68$ & $1929,39 \pm 1,03$ & $2012,52 \pm 14$ & $2093,39 \pm 4,62$ & $2145,42 \pm 7,99$ & $2112,78 \pm 10,16$ & 12209,06 \\
\hline \multirow[t]{2}{*}{ T4 } & $2129,48 \pm 0,91$ & $2168,10 \pm 5,76$ & $2051,10 \pm 24,07$ & $2056,59 \pm 8,08$ & $2189,34 \pm 9,63$ & $2183,56 \pm 6,82$ & 12778,17 \\
\hline & \multicolumn{7}{|c|}{ Bulk Density (g/L) } \\
\hline TO & $315,18 \pm 1,07$ & $309,58 \pm 1,76$ & $315,50 \pm 0,66$ & $313,83 \pm 0,77$ & $313,14 \pm 0,78$ & $319,63 \pm 2,44$ & 1886,86 \\
\hline $\mathrm{T} 1$ & $303,43 \pm 1,03$ & $296,13 \pm 1,08$ & $309,07 \pm 0,72$ & $314,20 \pm 0,06$ & $296,94 \pm 0,27$ & $301,80 \pm 1,1$ & 1821,58 \\
\hline $\mathrm{T} 2$ & $301,26 \pm 0,63$ & $301,05 \pm 0,56$ & $290,08 \pm 1,37$ & $290,98 \pm 1,07$ & $285,60 \pm 1,18$ & $285,14 \pm 0,82$ & 1754,10 \\
\hline T3 & $296,48 \pm 0,11$ & $292,06 \pm 0,16$ & $286,64 \pm 1,99$ & $287,95 \pm 0,64$ & $279,13 \pm 1,04$ & $271,07 \pm 1,3$ & 1713,34 \\
\hline T4 & $267,82 \pm 0,11$ & $265,41 \pm 0,71$ & $254,63 \pm 2,99$ & $245,77 \pm 0,97$ & $243,49 \pm 1,07$ & $240,42 \pm 0,75$ & 1517,55 \\
\hline
\end{tabular}

The interaction between the levels of treatment and incubation time using liquid waste biogas as a starter in the fermentation process of rice husk significantly affected $(P<0.01)$ the content of proximate, gross energy and the density of rice husk. The optimum interaction was observed in the provision of $15 \%$ liquid waste biogas which was incubated for 21 days.

The interaction between the level of provision and incubation time was associated with the number and growth of microorganisms in the liquid waste biogas. Microorganisms in the phase of balanced growth (metabolic activity constant) can concentrate decompose organic material contained in the substrate (Adli et al., 2019). Hidayat et al. (2013) explained that the bacterial cells would reach an optimum growth in media which provide sufficient nutrients. Lashkari et al. (2014) reported that supplementing a source of nitrogen in the raw silage material could increase total microbes and lower the $\mathrm{pH}$. The decreased $\mathrm{pH}$ due to the increasing total microbes during the fermentation would increase the digestibility of organic matter, protein production single cell; reshuffle the components of crude fiber and crude fat, carbohydrate formation; and increase the pores 
of the walls of the fibers which decreased the density of rice husk (Widiyawati, 2020).

\section{Conclusions}

Liquid waste biogas as a starter in the fermentation of rice husk could increase the content of inorganic material, crude protein, crude fat, and gross energy, and decrease the content of crude fiber and total density of rice husk.

\section{References}

Aderolu, A. Z., E. A. Ayiyi, and A. A. Onilude. 2007. Changes in Nutritional Value of Rice Husk during Trichoderma viride Degradation. Bulgarian Journal of Agricultural Science. 13 (7): 583-589.

Adli, D. N., O. Sjofjan and Mashudi. 2017. Dried of Poultry Waste Urea-Molasses Block (dpw-umb) as Potential for Feed Supplementation. Jurnal Agripet. 17(2): 144-149.

Adli, D. N. and O. Sjofjan. 2018. Nutrient content evaluation of dried poultry waste urea molasses block (DPW-UMB) on In-vitro analysis. Sains Peternakan. 16(2): 50-53.

Adli, D. N., O. Sjofjan and Mashudi. 2018. Nutrient content evaluation of dried poultry waste ureamolasses block (dpw-umb) on proximate analysis. Jurnal IImu-IImu Peternakan. 28(1): 8489.

Adli, D. N., Y. Chi, J. W. Lee and O. Sjofjan. 2019. Supplementation Mannan-Rich Fraction (MRF) and/or Combination with Probiotic-Enhanced Water Acidifier on Dietary Female Broiler at 28 days as Natural Growth Promoters (NGPs). Research Journal of Advanced Engineering and Science. 4(3): 427-429.

Adli, D. N., O. Sjofjan and Mashudi. 2019. Nutrient content evaluation of dried of poultry waste urea-molasses block (dpw-umb) on proximate analysis. Jurnal IImu dan Teknologi Peternakan. 6(2): 72-76.

Badan Pusat Statistik. 2014. Berita Resmi Statistik. Produksi Padi, Jagung, dan Kedelai: Angka Ramalan 1 Tahun 2014 : 1-10.

Bata, M. 2008. Pengaruh Molases pada Amoniasi Jerami Padi Menggunakan Urea terhadap Kecernaan Bahan Kering dan Bahan Organik InVitro. Jurnal Agripet, 1(3) : 15-20.

Daniel, O Sjofjan and I. H. Djunaidi. 2014. Kajian Kandungan Zat Makanan dan Pigmen Antosianin Tiga Jenis Kulit Buah Naga (Hylocereus sp) sebagai Bahan Pakan Ternak. Jurnal Ilmu-ilmu Peternakan, 12(5): 1-9.
Fang, H. H. P., C. Li and T. Zhang. 2006. Acidophilic Biohydrogen Production from Rice Slurry. International Journal of Hydro gen Energy. 11(3) : 683-692.

Gamayanti, K. N., A. Pertiwiningrum and L. M. Yusiati. 2012. Pengaruh Penggunaan Limbah Cairan Rumen dan Lumpur Gambut sebagai Starter dalam Proses Fermentasi Metanogenik. Buletin Peternakan. 3(4) : 32-39.

Hidayat, I. R., Kusrahayu and S. Mulyani. 2013. Total Bakteri Asam Laktat, Nilai ph dan Sifat Organoleptik Drink Yoghurt dari Susu Sapi yang diperkaya dengan Ekstrat Buah Mangga. Animal Agriculture Journal. 17(6) : 162-163.

Joseph, I., R. P. Raj and D. Bhatnagar. 2008. Effect of solid state fermentation on nutrient composition of selected ingredients. Indian Journal of Fish. 12(1) : 327-332.

Lashkari, S., A. Taghizadeh, J. Selfidayati and A. Z. M. Salem. 2014. Qualitative Characteristics, Microbial Populations and Nutritive values of Orange Pulp Ensiled with Nitrogen Supplementation. Slovakian Journal Animal Science. 8(9) : 90-99.

Ligyarohman, F., M. H. Natsir and I. H. Djunaidi. 2014. Pengaruh Pemberian Level Dedak yang berbeda dengan Penambahan Xilanase dalam pakan terhadap Berat Organ Dalam dan Kualitas Karkas Ayam Pedaging. Jurnal Ilmu-ilmu peternakan. 5(6) : 1-6.

Lunar, A. M., H. Supratman and Abun. 2012. Pengaruh Dosis Inokulum dan Lama Fermentasi Buah Ketapang (Ficus lyrata) oleh Aspergilus niger terhadap Bahan Kering, Serat Kasar, dan Energy Bruto. Jurnal nutrisi ternak dan pakan tropis, 2(3) : 1-6.

Mangunwidjaja, D., T. E. Sukmaratri and C. Setiyarto. 2015. Peningkatan Kadar Protein Kasar Ampas Kulit Nanas melalui Fermentasi Media Padat. Buletin Peternakan. 3(4): 12-16.

Mirwandhono, E., I. Bachari and D. Situmorang. 2006. Uji nilai nutrisi kulit ubi kayu yang difermentasi dengan Aspergillus niger. Jurnal Agribisnis Perternakan. 2 (3): 91-95.

Nasution, D. Y. 2006. Pengaruh Ukuran Partikel dan Berat Abu Sekam Padi sebagai Pengisi terhadap Sifat Kuat Sobek, Kekerasan, dan Ketahanan Abrasi Kompon. Jurnal Sains Kimia. 10 (2): 86-91.

Prabhu, A. A., C. M. Mrudula and J. Rajesh. 2014. Effect of Yeast Fermentation on Nutraceutical and Antioxidant Properties of Rice Bran. International Journal of Agricultural and Food Science. 2(3) : 59-65.

Safitri, R. 2014. The Influence of Fermentation by Bacillus circulans, Micrococcus sp., and $B$. coagulans Towards Fat, Crude Fiber and Protein 
Content of Palm Oil Empty Fruit Bunches Waste (Elaeis guineensis Jacq.). University of Agricultural Sciences and Veterinary Medicine, Surabaya.

Safitri, R. and R. R. Wahyudi. 2011. Effect of Consortium Trichoderma viride, Trichoderma reesei, Aspergillus oryzae and Rhizopus oligosporus, and Dose on Inoculant Viability, Reducing Sugar and Nutritional Value of Corn Cobs. International Seminar Biotechnology : Agustus 2011. Pp:33-46.

Sjofjan, O., D. N. Adli, P. K. Hanani and D. Sulistiyaningrum. 2019. The utilization of bay leaf (SyzygiumpolyanthumWalp) Flour in feed on carcass quality, microflora instestine of broiler. International Journal of Engineering Technologies and Management Research. 6(11):1-9.

Sjofjan, O., D. N. Adli, M. H. Natsir and A. Kusumaningtyaswati. 2020. Pengaruh kombinasi tepung kunyit (curcuma domestica val.) dan probiotik terhadap penampilan usus ayam pedaging. Jurnal Nutrisi Ternak Tropis dan IImu Pakan. 2 (1):19-24.
Suparjo and Nelson. 2011. Penentuan Lama Fermentasi Kulit Buah Kakao dengan Phanerochaete chrysosporium : Evaluasi Kualitas Nutrisi secara Kimiawi. Agrinak. 1(2) : 1-10.

Suryanata, I. K., I. H. Djunaidi and M. H. Natsir. 2013. Pengaruh Penambahan Xylanase dalam pakan dengan Level Dedak yang Berbeda terhadap Kualitas Fisik Daging Ayam Pedaging. Jurnal IImuIlmu Peternakan. 1(3): 1-8.

Telew, C., V. G. Kereh, I. M. Unt and B. W. Rembet. 2013. Pengayaan Nilai Nutritif Sekam Padi berbasis Bioteknologi "Effective Mikroorganisms" (EM4) sebagai Bahan Pakan Organik. Jurnal Zootek. 32 (5): 1-8.

Widiyawati, I., O. Sjofjan and D. N. Adli. 2020. Peningkatan Kualitas dan Persentase Karkas Ayam Pedaging dengan Subtitusi Bungkil Kedelai Menggunakan Tepung Biji Asam (Tamarindus indica $L$ ) Fermentasi. Jurnal Nutrisi Ternak Tropis. 3(1): 35-40.

Yunilas. 2009. Bioteknologi Jerami Padi melalui Fermentasi sebagai Bahan Pakan Ternak Ruminansia, Medan. 